\title{
Patients' Perceptions About Medical Record Privacy and Security: Implications for Withholding of Information During the COVID-19 Pandemic
}

$\mathrm{J}$ Gen Intern Med 35(10):3122-5

DOI: $10.1007 / \mathrm{s} 11606-020-05998-6$

(c) Society of General Internal Medicine 2020

\section{INTRODUCTION}

Some patients may withhold relevant medical information from their provider because of concerns about the security and privacy of their information, or about how their information will be used. ${ }^{1}$ With increasing reliance on telemedicine and telehealth tools (e.g., patient portals) in response to the coronavirus disease 2019 (COVID-19) pandemic, this issue may be particularly problematic. As withholding information can compromise providers' ability to deliver appropriate care, the accuracy of public health surveillance system data, and even population health efforts to mitigate the spread of COVID-19, we need to understand how patients' concerns about the privacy and security of their medical information may lead to information-withholding behaviors.

\section{METHODS}

Data for the present study came from a survey administered to patients hospitalized at a large academic medical center (AMC) enrolled in a pragmatic randomized controlled trial (RCT). ${ }^{2}$ The RCT studied the relationship between inpatient portal use and patients' care experience. One survey section asked about patients' attitudes toward use of health information technology, including their perceptions about information security risks and privacy. These questions were adapted from the National Cancer Institute's Health Information Technology National Trends Survey. The Institutional Review Board of the AMC approved this study.

The dependent variable for this study was the answer to the question "Have you ever kept information from your healthcare provider because you were concerned about the privacy or security of your medical record?" (yes/no). On the basis of previous research, ${ }^{3}$ we included four independent variables derived from answers to questions about medical information privacy and security:

Received May 25, 2020

Accepted June 15, 2020

Published online July 31, 2020
1. "If your medical information is sent electronically from one health provider to another, how concerned are you that an unauthorized person will see it?"

2. "How confident are you that you have some say in who is allowed to collect, use, and share your medical information?"

3. "How confident are you that safeguards (including the use of technology) are in place to protect your medical records from being seen by people who aren't permitted to see them?"

4. "How interested are you in exchanging medical information electronically with a healthcare provider?"

A multivariable logistic regression model was used to test the relationship of the independent variables with informationwithholding behavior, adjusting for patient demographics.

\section{RESULTS}

Table 1 summarizes patient characteristics and survey responses of our study participants. Results of our regression analysis (Table 2) show that for patients who were concerned that their medical information would be compromised if it was sent electronically between providers, the odds of withholding information from their provider was three times that of patients without concerns. Conversely, for patients who were confident about the privacy of their medical information, the odds of keeping information from their provider was approximately half of those who were not confident. Black patients were generally more likely to withhold information compared with White patients. Patients who were older, married, employed, and in good mental health and who had healthcare coverage were less likely to keep information from their provider.

\section{DISCUSSION}

Similar to previous research conducted in the general population, ${ }^{3,4}$ our findings suggest that many hospitalized patients are concerned about who has access to their medical information, and we found an association between these concerns and patients' reported information-withholding behavior. While these findings were limited to the perceptions of patients from a single AMC, they are nonetheless important for providers to consider given relaxation of Health Insurance Portability and 
Table 1 Frequencies of Information-Withholding Behavior, Privacy and Security Concerns, and Patient Characteristics

\begin{tabular}{|c|c|c|}
\hline Question & Answer & $N=3292$ \\
\hline \multicolumn{2}{|l|}{ Dependent variable } & $n(\%)^{*}$ \\
\hline Kept information secret: have you ever kept information from your healthcare provider because you were & No & $2438(74.1)$ \\
\hline \multirow[t]{2}{*}{ concerned about the privacy or security of your medical record? } & Yes & $349(10.6)$ \\
\hline & Missing & $505(15.3)$ \\
\hline \multicolumn{3}{|l|}{ Independent variable } \\
\hline Unauthorized access: if your medical information is sent electronically from one health provider to another, & Not concerned & $1091(33.1)$ \\
\hline \multirow{2}{*}{ how concerned are you that an unauthorized person will see it? } & Concerned & $1738(52.8)$ \\
\hline & Missing & $463(14.1)$ \\
\hline Have say about medical information: how confident are you that you have some say in who is allowed to & Not confident & $1414(43.0)$ \\
\hline \multirow{2}{*}{ collect, use, and share your medical information? } & Confident & $1519(46.1)$ \\
\hline & Missing & $359(10.9)$ \\
\hline \multirow{3}{*}{$\begin{array}{l}\text { Safeguards in place: how confident are you that safeguards (including the use of technology) are in place to } \\
\text { protect your medical records from being seen by people who aren't permitted to see them? }\end{array}$} & Not confident & $1674(50.9)$ \\
\hline & Confident & $1129(34.3)$ \\
\hline & Missing & $489(14.9)$ \\
\hline \multirow{3}{*}{$\begin{array}{l}\text { Exchanging information electronically: how interested are you in exchanging medical information } \\
\text { electronically with a healthcare provider? }\end{array}$} & Not interested & $938(28.5)$ \\
\hline & Interested & $1935(58.8)$ \\
\hline & Missing & $419(12.7)$ \\
\hline \multicolumn{3}{|l|}{ Patient characteristic } \\
\hline \multirow[t]{3}{*}{$\operatorname{Race}^{\dagger}$} & White & $2574(78.2)$ \\
\hline & Black & $593(18.0)$ \\
\hline & Other & $125(3.8)$ \\
\hline \multirow[t]{2}{*}{ Gender $^{\dagger}$} & Female & 1972 (59.9) \\
\hline & Male & $1320(40.1)$ \\
\hline $\mathrm{Age}^{\dagger}$ & Mean (SD) & $46.8(15.0)$ \\
\hline \multirow[t]{3}{*}{ Marital status: what is your marital status? } & Not married & $1390(42.2)$ \\
\hline & Married & $1251(38.0)$ \\
\hline & Missing & $651(19.8)$ \\
\hline \multirow[t]{6}{*}{ Education: what is the highest grade or level of school that you have completed? } & $\begin{array}{l}\text { Less than high } \\
\text { school }\end{array}$ & $154(4.7)$ \\
\hline & High school & $724(22.0)$ \\
\hline & Some college & $828(25.2)$ \\
\hline & College graduate & $712(21.6)$ \\
\hline & Graduate or beyond & $326(9.9)$ \\
\hline & Missing & $548(16.6)$ \\
\hline Household income: in the last 12 months, what is your total household income, including income from all & $\$ 0-\$ 19,999$ & $893(27.1)$ \\
\hline \multirow[t]{6}{*}{ sources (wages, salaries, investment income, Social Security, retirement benefits, or help from a relative)? } & $\$ 20,000-\$ 34,999$ & $387(11.8)$ \\
\hline & $\$ 35,000-\$ 49,999$ & $272(8.3)$ \\
\hline & $\$ 50,000-\$ 74,999$ & $364(11.1)$ \\
\hline & $\$ 75,000-\$ 99,999$ & $232(7.0)$ \\
\hline & $\$ 100,000$ or more & $373(11.3)$ \\
\hline & Missing & $771(23.4)$ \\
\hline \multirow[t]{4}{*}{ Employment: which of the following best describes your employment status last week? } & Unemployed & $1160(35.2)$ \\
\hline & Employed & $1146(34.8)$ \\
\hline & Retired & $341(10.4)$ \\
\hline & Missing & $645(19.6)$ \\
\hline \multirow{3}{*}{$\begin{array}{l}\text { Healthcare coverage: do you have any kind of healthcare coverage, including health insurance, prepaid } \\
\text { plans such as HMOs, or government plans such as Medicaid/Medicare? }\end{array}$} & No & $213(6.5)$ \\
\hline & Yes & $2387(72.5)$ \\
\hline & Missing & $692(21.0)$ \\
\hline \multirow[t]{3}{*}{ Self-care: I am confident that I know how to take care of my health... } & Do not agree & $1638(49.8)$ \\
\hline & Agree & $1320(40.1)$ \\
\hline & Missing & $334(10.1)$ \\
\hline \multirow[t]{3}{*}{ General health: would you say your health is... } & Not good & $1315(39.9)$ \\
\hline & Good & $1375(41.8)$ \\
\hline & Missing & $602(18.3)$ \\
\hline \multirow[t]{3}{*}{ Mental health: how would you rate your mental health, including your mood and your ability to think? } & Not good & $1408(42.8)$ \\
\hline & Good & $1262(38.3)$ \\
\hline & Missing & $622(18.9)$ \\
\hline
\end{tabular}

*Unless noted otherwise

${ }^{\dagger}$ Data derived from the academic medical center's information warehouse

Accountability Act (HIPAA) protections in response to COVID-19. Specifically, the U.S. Office for Civil Rights has granted business associates (e.g., healthcare clearinghouses) the ability to make good-faith disclosures of personal medical information for public health activities as long as the patient is informed within 10 days. ${ }^{5}$

In order to protect against potential adverse impacts of this rule on disclosure, providers likely need to reinforce technological safeguards, such as secure and encrypted communication, and clearly communicate about how patients' medical information is accessed, stored, and used in order to honor patient privacy preferences ${ }^{6}$ and potentially address patients' concerns in this area. Monitoring the impact of these changes on patients' information-withholding behavior will be critical to ensure providers have the appropriate information to enable delivery of high-quality care. 
Table 2 Multivariable Logistic Regression Model for Patient Information-Withholding Behavior

\begin{tabular}{|c|c|c|c|}
\hline \multirow[b]{3}{*}{ Independent variable ${ }^{*}$} & \multicolumn{3}{|c|}{$\begin{array}{l}\text { Have you ever kept information from your healthcare provider because you were concerned } \\
\text { about the privacy or security of your medical record? }\end{array}$} \\
\hline & \multirow{2}{*}{$\frac{\text { No }}{n(\%)}$} & \multirow{2}{*}{$\frac{\text { Yes }}{n(\%)}$} & \multirow[t]{2}{*}{ Adjusted OR (95\% CI) } \\
\hline & & & \\
\hline \multicolumn{4}{|l|}{ Unauthorized access } \\
\hline Not concerned & $1026(42.1)$ & $55(15.9)$ & - \\
\hline Concerned & $1410(57.9)$ & $291(84.1)$ & $3.26(2.26-4.78)$ \\
\hline \multicolumn{4}{|c|}{ Have say about medical information } \\
\hline Not confident & $1116(46.0)$ & $210(61.0)$ & - \\
\hline Confident & $1312(54.0)$ & $134(39.0)$ & $0.48(0.33-0.69)$ \\
\hline \multicolumn{4}{|l|}{ Safeguards in place } \\
\hline Not confident & $1424(58.6)$ & $236(67.8)$ & - \\
\hline Confident & $1008(41.4)$ & $112(32.2)$ & $1.26(0.86-1.84)$ \\
\hline \multicolumn{4}{|c|}{ Exchanging information electronically } \\
\hline Not interested & $791(32.5)$ & $125(35.9)$ & - \\
\hline Interested & $1644(67.5)$ & $223(64.1)$ & $1.19(0.87-1.63)$ \\
\hline \multicolumn{4}{|l|}{ Race } \\
\hline White & $1974(81.0)$ & $246(70.5)$ & - \\
\hline Black & $379(15.5)$ & $85(24.4)$ & $1.55(1.07-2.20)$ \\
\hline Other & $85(3.5)$ & $18(5.2)$ & $1.27(0.60-2.48)$ \\
\hline \multicolumn{4}{|l|}{ Gender } \\
\hline Female & $1461(59.9)$ & $201(57.6)$ & - \\
\hline Male & $977(40.1)$ & $148(42.4)$ & $1.20(0.89-1.61)$ \\
\hline \multicolumn{4}{|r|}{ 1. } \\
\hline Mean (SD) & $47.0(15.1)$ & $44.4(12.6)$ & $0.99(0.98-1.00)$ \\
\hline \multicolumn{4}{|l|}{ Marital status } \\
\hline Not married & $1105(50.1)$ & $211(69.6)$ & - \\
\hline Married & $1100(49.9)$ & $92(30.4)$ & $0.59(0.41-0.84)$ \\
\hline \multicolumn{4}{|l|}{ Education } \\
\hline Less than high school & $115(5.0)$ & $34(10.8)$ & - \\
\hline High school & $598(26.1)$ & $86(27.4)$ & $0.75(0.44-1.31)$ \\
\hline Some college & $694(30.3)$ & $100(31.8)$ & $0.68(0.40-1.19)$ \\
\hline College graduate & $605(26.4)$ & $66(21.0)$ & $0.69(0.38-1.27)$ \\
\hline Graduate or beyond & $278(12.1)$ & $28(8.9)$ & $0.70(0.34-1.45)$ \\
\hline \multicolumn{4}{|l|}{ Household income } \\
\hline$\$ 0-\$ 19,999$ & $708(33.3)$ & $151(53.0)$ & - \\
\hline$\$ 20,000-\$ 34,999$ & $342(16.1)$ & $31(10.9)$ & $0.53(0.32-0.87)$ \\
\hline$\$ 35,000-\$ 49,999$ & $240(11.3)$ & $15(5.3)$ & $0.48(0.24-0.90)$ \\
\hline$\$ 50,000-\$ 74,999$ & $313(14.7)$ & $39(13.7)$ & $1.13(0.68-1.84)$ \\
\hline$\$ 75,000-\$ 99,999$ & $205(9.6)$ & $16(5.6)$ & $0.70(0.34-1.34)$ \\
\hline$\$ 100,000$ or more & $321(15.1)$ & 33 (11.6) & $1.34(0.74-2.39)$ \\
\hline \multicolumn{4}{|l|}{ Employment } \\
\hline Unemployed & $927(41.8)$ & $174(59.0)$ & - \\
\hline Employed & $996(44.9)$ & $98(33.2)$ & $0.68(0.47-0.97)$ \\
\hline Retired & $294(13.3)$ & $23(7.8)$ & $0.85(0.45-1.55)$ \\
\hline \multicolumn{4}{|l|}{ Healthcare coverage } \\
\hline No & $171(7.7)$ & 34 (11.6) & - \\
\hline Yes & $2043(92.3)$ & $258(88.4)$ & $0.57(0.37-0.92)$ \\
\hline \multicolumn{4}{|l|}{ Self-care } \\
\hline Do not agree & $1265(53.9)$ & $212(63.5)$ & - \\
\hline Agree & $1084(46.1)$ & $122(36.5)$ & $0.80(0.58-1.08)$ \\
\hline \multicolumn{4}{|l|}{ General health } \\
\hline Not good & $1083(47.8)$ & $166(53.4)$ & - \\
\hline Good & $1182(52.2)$ & $145(46.6)$ & $1.19(0.86-1.65)$ \\
\hline Mental health & & & \\
\hline Not good & $1148(50.9)$ & $205(66.6)$ & - \\
\hline Good & 1107 (49.1) & $103(33.4)$ & $0.66(0.47-0.91)$ \\
\hline
\end{tabular}

*Definitions for each variable can be found in Table 1

Acknowledgments: The authors wish to thank Alice Gaughan, Lindsey Sova, Jaclyn Volney, Danijela Cvijetinovic, Toby Weinert, Allison Silverman, Ayanna Scott, and Karen Alexander, all affiliated with the authors' organization, for their assistance with this project, and all the participants in this study.

Matthew J. DePuccio, PhD, MS ${ }^{1}$

Gennaro Di Tosto, $P h D^{1}$

Daniel M. Walker, $P h D, M P H^{1,2,3}$

Ann Scheck McAlearney, ScD, MS $S^{1,2,3}$
${ }^{1}$ The Center for the Advancement of Team Science, Analytics, and Systems Thinking in Health Services and Implementation Science Research (CATALYST), College of Medicine, The Ohio State University,

Columbus, $\mathrm{OH}$, USA

${ }^{2}$ The Department of Family and Community Medicine, College of Medicine, The Ohio State 
University,

Columbus, OH, USA

${ }^{3}$ The Department of Biomedical Informatics, College of Medicine, The Ohio State University,

\section{Columbus, $\mathrm{OH}$, USA}

Corresponding Author: Matthew J. DePuccio, PhD, MS; The Center for the Advancement of Team Science, Analytics, and Systems Thinking in Health Services and Implementation Science Research (CATALYST), College of Medicine, The Ohio State University Columbus, OH, USA (e-mail: Matthew.DePuccio@osumc.edu).

Funding Information This research was supported by grants from the Agency for Healthcare Research on Quality (Grant No. P3OHSO24379, Grant No. RO1HSO24091 and Grant No. R21HSO24767).

\section{Compliance with Ethical Standards:}

Conflict of Interest: The authors declare that they do not have a conflict of interest.

Disclaimer: While this research was funded by the Agency for Healthcare Research and Quality, the study sponsor had no involvement in the collection, analysis, or interpretation of data; in the writing of this manuscript; or in the decision to submit the manuscript for publication.

\section{REFERENCES}

1. Abdelhamid M, Gaia J, Sanders GL. Putting the Focus Back on the Patient: How Privacy Concerns Affect Personal Health Information Sharing Intentions. J Med Internet Res. 2017;19(9):e169.

2. McAlearney AS, Sieck CJ, Hefner JL, et al. High Touch and High Tech (HT2) Proposal: Transforming Patient Engagement Throughout the Continuum of Care by Engaging Patients with Portal Technology at the Bedside. JMIR Res Protoc. 2016;5(4):e221.

3. Agaku IT, Adisa AO, Ayo-Yusuf OA, Connolly GN. Concern about security and privacy, and perceived control over collection and use of health information are related to withholding of health information from healthcare providers. J Am Med Inform Assoc. 2014;21(2):374-378.

4. Walker DM, Johnson T, Ford EW, Huerta TR. Trust Me, I'm a Doctor: Examining Changes in How Privacy Concerns Affect Patient Withholding Behavior. J Med Internet Res. 2017;19(1):e2.

5. Department of Health and Human Services. Notification of enforcement discretion under HIPAA to allow uses and disclosures of protected health information by business associates for public health and health oversight activities in response to COVID-19 (45 CFR Parts 160 and 164). Published 2020. Available at: https://www.hhs.gov/sites/default/files/notificationenforcement-discretion-hipaa.pdf?language=en. Accessed May 4, 2020.

6. Chaet $\mathbf{D}$, Clearfield $\mathbf{R}$, Sabin JE, Skimming $\mathbf{K}$. Ethical practice in Telehealth and Telemedicine. J Gen Intern Med. 2017;32(10):1136-1140.

Publisher's Note: Springer Nature remains neutral with regard to jurisdictional claims in published maps and institutional affiliations. 